\title{
The foundation of the Hospital Infantil de México, today Hospital Infantil de México Federico Gómez
}

\author{
Manuel A. Baeza-Bacab ${ }^{1 *}$, Juan J. Luis Sienra-Monge ${ }^{2}$ and Horacio L. Reyes-Vázquez ${ }^{3}$ \\ ${ }^{1}$ Facultad de Medicina, Universidad Autónoma de Yucatán, Mérida, Yucatán; ${ }^{2}$ Hospital Infantil de México Federico Gómez, Mexico City; \\ Pigüi, Hospital Español, Mexico City. Mexico
}

\begin{abstract}
In the early years of the $20^{\text {th }}$ century, no hospital in Mexico held the capacity to address the health problems of Mexican children, making it necessary to build a modern institution to take care of these issues. This situation mobilized a group of doctors led by Dr. Federico Gómez Santos to seek the acknowledgement of the President, Abelardo L. Rodríguez, off the urgent need of a children's hospital. Later, the President approved the project for its construction in 1933. After 10 years of struggle in the political, social and economic fields, and with the support of presidents Lázaro Cárdenas and Manuel Ávila Camacho, the Hospital Infantil de México was inaugurated on April 30 $0^{\text {th }}, 1943$. Today, 75 years after its creation, the hospital has withstood the test of time maintaining intact its principles of assistance, teaching and research, and emerging as, the cradle of Mexican and Latin American pediatrics.
\end{abstract}

Key words: Hospital. Pediatrics. History. Infancy. Mexico.

\section{La fundación del Hospital Infantil de México, ahora Hospital Infantil de México Federico} Gómez

\section{Resumen}

En los primeros años del siglo XX, no existía en México un hospital que tuviera la capacidad de atender los problemas de salud de la niñez mexicana, lo que hacía necesaria la construcción de una institución moderna para atenderlos. En 1933 , esta situación llevó a un grupo de médicos, encabezados por el Dr. Federico Gómez Santos, a solicitar y conseguirđque el presidente de la República, Abelardo L. Rodríguez, reconociera la imperiosa necesidad de contar con un hospital de niños y aprobara el proyecto para su construcción. Luego de diez años de lucha en el campo político, social y económico, y con el apoyo de los presidentes Lázaro Cárdenas y Manuel Ávila Camacho, el 30 de abril de 1943 se inauguró el Hiospital Infantil de México. Hoy, después de 75 años de su creación, el hospital ha resistido la prueba del tiempo y mantiene incólume sus principios de asistencia, enseñanza e investigación, emergiendo como la cuna de la pediatría mexicana y latinoamericana.

Palabras clave: Hospital. Pediatría. Historia. Infancia. México. 


\section{Introduction}

Seventy-five years ago, on April 30, 1943, after ten years of struggle in the political, social, and economic field, the Hospital Infantil de México was inaugurated. With the passing of time and giving a fair recognition, the hospital adopted the name of its founder, Dr. Federico Gómez Santos, about whom Dr. Jesús Kumate said: "he is the creator of the Mexican pediatric school, founder of the Hospital Infantil and scholar of the Latin American pediatrics" (Fig. 1). ${ }^{1}$ Therefore, it can be concluded that his magnificent and immortal work, the Hospital Infantil de México, is the cradle of the national and Latin American pediatrics.

The present work is only a brief memorial of its foundation and the names of men and women who, overcoming the accumulating obstacles, made this invaluable work that has endured and has grown over time. It is a modest tribute, not only for those who made it possible but to all the individuals who have collaborated with their aggrandizement over the last 75 years.

\section{Childcare in the early twentieth century}

In the early years of the twentieth century, children's health care in Mexico City depended on the pediatric wards of the Hospital General, Hospital Juárez and, principally, of the Casa de Niños Expósitos, better known as Casa Cuna. In 1938, a small children's hospital called Dolores Sanz de Lavie also started operating. ${ }^{2}$

In his work, "Las tres primeras instituciones dedicadas a la asistencia hospitalaria pediátrica en México" [The first three institutions dedicated to pediatric hospital care in Mexico], Dr. Jesús Lozoya Solís, one of the founders of the Hospital Infantil de México, said that the scientific splendor of the Casa Cuna began with the arrival of Dr. Manuel Cárdenas de la Vega to manage that institution in 1931. During his administration, Casa Cuna moved to a new location located on Hidalgo Street, in Coyoacán (Fig. 2). The amplitude of the facilities allowed the transformation of the asylum of abandoned children into a hospital where they were treated integrally and carefully. In this place, there was a pediatric service as there was no other in Mexico, as it had the necessary staff, doctors and nurses, and the services of otolaryngology, ophthalmology, dermatology, clinical analysis laboratory, X-ray cabinet, in addition to a kitchen for the preparation of particular feeding formulas. ${ }^{3}$

A clinical history of all the admitted children was made to prepare an accurate diagnosis of their health

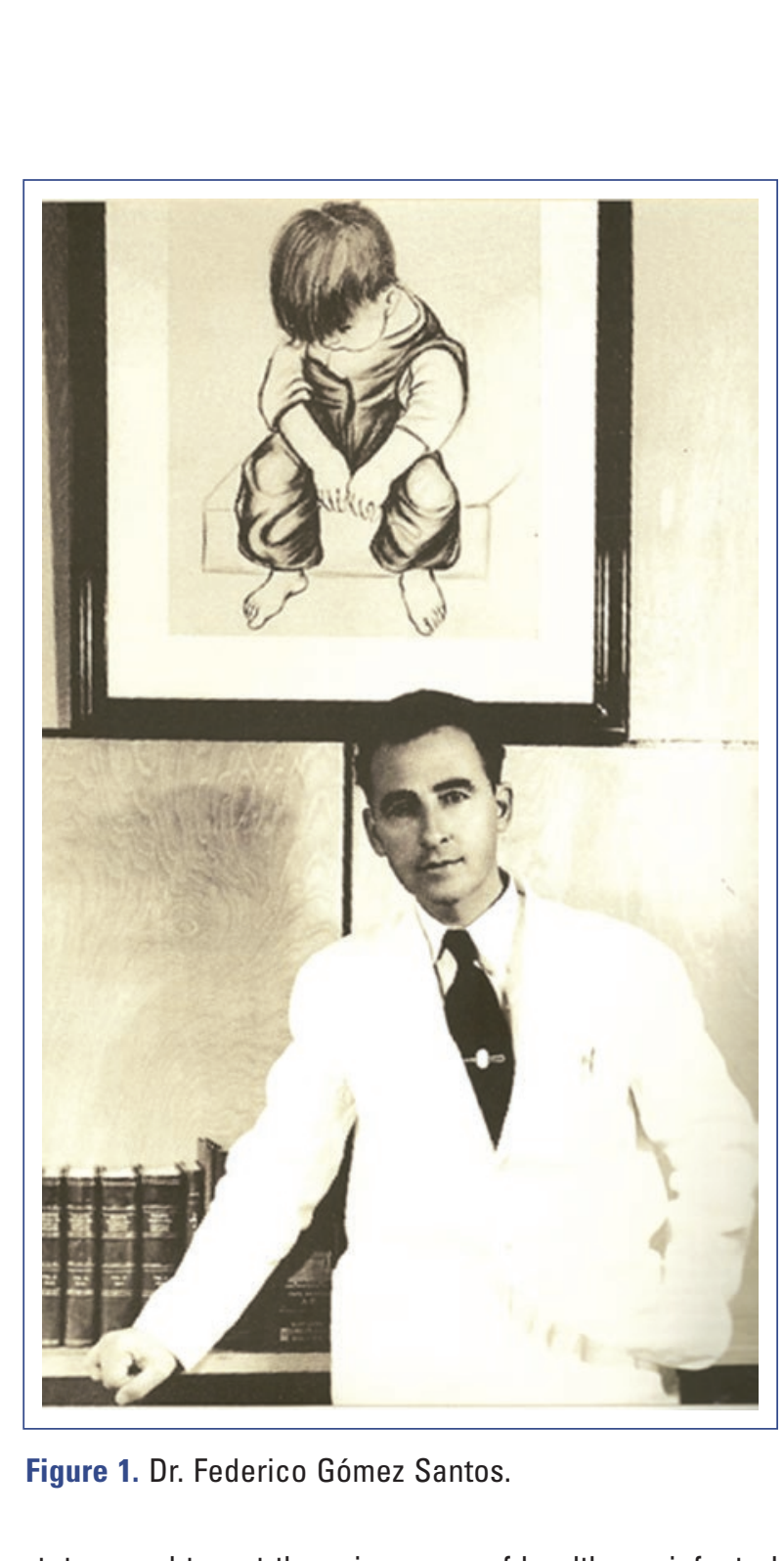

status, and to put them in rooms of healthy or infected children, according to their age. At that time, the person in charge of the nursery room was Dr. Federico Gómez Santos, who succeed in having the room with individual cubicles with wood and glass divisions instead of cradles next to each other in long rows. ${ }^{3,4}$

The latter motivated Romulo Velazco to write the following: "The Casa Cuna, without any exaggeration, is the excellence center of doctors who are dedicated to the diseases of children in Mexico City". ${ }^{5}$ However, neither the Casa Cuna nor the pediatric wards of the existing hospitals could meet the health needs of Mexican children, which made it clear the need for a-children's hospital.

\section{A favorable environment}

The beginning of the third decade of the twentieth century was helpful for the national pediatric care development, as several actions were taken to supporting 


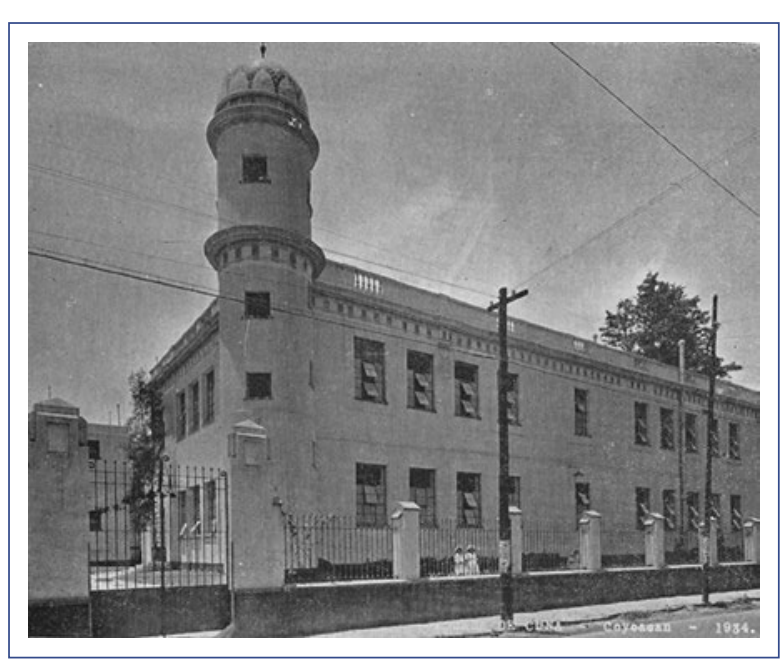

Figure 2. Casa Cuna, Coyoacán, 1934.

children. For instance, the Congresos Mexicanos del Niño [Mexican Children's Congresses], sponsored by the engineer Felix Palavicini, director of the EI Universal newspaper during 1921 and 1922, which brought together numerous doctors, lawyers and professors to present their opinion on the state in which Mexican children lived, as well as the actions they deemed necessary to reduce high mortality rates, improve child's feeding, hygiene habits, and education, as well as generate adequate laws. Also, in 1922, Dr. Isidro Espinosa de los Reyes accomplished the construction of the first Child Hygiene Center. The creation of the Child Hygiene Service was done in 1927, with the support of the head of the Health Department, Dr. Aquilino Villanueva, and two years later, the National Association for Child Protection was created. In 1938, Dr. Espinosa brought together a select group of obstetricians and pediatricians at the Sociedad Mexicana de Puericultura [Mexican Society for Childcare]. In 1940 this society was transformed into the Sociedad Mexicana de Pediatría [Mexican Society of Pediatrics], to which only doctors who were committed to the health of children, particularly those who worked in the Child Hygiene Centers and Casa Cuna, have joined. ${ }^{4,6}$

The Society used to meet once a month in the auditorium of the Escuela Nacional de Medicina [National School of Medicine], where various works directed to pediatric problems were presented, which evidenced the need for specialized childcare services. In this way, the Society became a seedbed of enthusiasm, projects, and ideas for the advancement of the new pediatric trends in Mexico. At the end of the scientific meetings, the attendees routinely ended up in the Café de Tacuba, where they poured, for hours, animated comments and suggestions to have a children's hospital in Mexico. ${ }^{4}$

According to Dr. Lozoya, another important meeting place was the house of Dr. Mario A. Torroella, deputy chief of the Child Hygiene Service, where he organized scientific-literary evenings, with the participation of Manuel Cárdenas de la Vega, Federico Gómez, Rigoberto Aguilar Pico, Pablo Mendizábal, and the young architect José Villagrán García, building with a great insight in these meetings the bases of the friendly and fruitful treatment which would become one obthe characteristics of Mexican pediatricians. According to the author, the first project for the construction and organization of the Hospital Infantil de México emerged from these meetings. ${ }^{3}$

However, the political environment did not seem to realize the helplessness of sick children or the growing pediatric concern. Thus, Dr. Federico Gómez recalls that his private practice led him to attend the grandehildren of Mr. Pedro Malabehar Peña, editor-in-chief of the El Universal newspaper, who was interested in the idea of building a modern children's hospital in Mexico, so he made available the columns of his editorial page available to Dr. Gomez. From that moment, once a week for four or five years, articles directed to the government and the general public, that described what several countries were doing in favor of their children to protect them in health and disease, appeared. Albthe articles ended with a distressing message, emphasizing the need to establish a modern institution that fook care of the large number of sick children. ${ }^{4}$

\section{The first proposal}

Although the federal government in 1920, and the Cruz Blanca Neutral [Neutral White Cross] in 1922, intended to create a children's hospital, the projects did not progress. The formal opportunity was presented with the political changes of 1932, which led General Abelardo L. Rodríguez, a prominent military and politician from the northwest of the country to the Presidency of the Republic. His physician, Dr. Mariano Rongero Ochoa, was a friend of Rigoberto Aguilar Pico and Federico Gómez, and he had heard them on several occasions speaking with enthusiasm and conviction about the urgent need for a children's hospital. Dr. Romero, a sympathizer of that idea despite nofbeing a pediatrician, promised to give President Rodríguez a letter signed by the three physicians requesting that the government take the necessary steps for Mexican children to have a hospital. After several 
weeks of impatience and doubts, the President of the Republic sent a reply letter, dated May 31 $31^{\text {st }}$, 1933: "I find that, indeed, there is an urgent need for a hospital for children, and I will gladly discuss the matter with the head of the Central Department, as well as with the director of Charity, in order to study and carry out your project". 4,7

After a short time, the head of the Central Department, Lic. Aarón Sáenz, and the director of the Public Charity, General José María Tapia, met and decided that a group of engineers would take charge of the project to build the mentioned hospital. Finally, a commission was appointed to advise the building engineers. This commission was formed by Dr. Fernando Ocaranza, medical member of the Charity Board of Directors; Dr. José Castro Villagrana, director of the Hospital Juárez; Dr. Manuel Guevara Oropeza, director of the mental hospital La Castañeda; and Dr. Manuel Cárdenas de la Vega, director of the Casa Cuna. ${ }^{4}$

Dr. Federico Gomez said that when the beginning of the construction of the Hospital del Niño was known, the Sociedad Mexicana de Puericultura [Mexican Society for Childcare] called for a session, in which it was decided to offer the collaboration of a group of pediatricians able of advising about the functional aspects of the project and the general distribution and capacity of the different services to the medical commission of the Public Charitable. This commission was formed by Dr. Mario Torroella, Dr. Pablo Mendizábal, and Dr. Federico Gómez himself. Those involved went with great enthusiasm with Dr. Fernando Ocaranza, medical spokesman of the Public Charity, who ended their illusions by issuing a resounding rejection because, according to Dr. Ocaranza, the commission formed by the Medical Department of the Public Charity was sufficiently capable of advising the Department of Engineers about the construction of the Children's Hospital, for which he officially "thanked" the Mexican Society of Childcare for their offer and dispatched the commission without remorse. ${ }^{4}$

\section{The planning and construction begin}

In 1933, the new hospital planning work began. The brightest ideas came from Dr. Manuel Cárdenas de la Vega who pointed out the need to differentiate children who require hospitalization, the possibility of admitting the mother along with her child, the need of providing specialized care based on the availability of specialized doctors and nurses, the necessity of separating children according to their age and to have a pavilion to respond to the demand of people with sufficient financial resources for hospital care. After two months of work, they had the idea of constructing a multi-story building with 500 beds according to the calculated needs.

By December 1933, there were already the hospital building designs prepared by the engineer Alberto $\mathrm{Ba}$ rocio, who chose a comb-shaped construction with six extensions, on which solariums and terraces were planned. The area chosen for the construction of the Hospital del Niño was located behind the General Hospital: a lot of $20,000 \mathrm{~m}^{2}$ where vegetables used to be planted. Construction began on March 3, $1934 .{ }^{\circ}$

\section{The first storm clouds}

The first bad news for the emerging project was the premature death, on October 26, 1934, of Dr. Manuel Cárdenas de la Vega. This event seemed to stopthe improvement of the Casa Cuna and the construction of the hospital. However, both projects fell under the direction of Dr. Federico Gómez, who was commissioned medical advisor of the Department of Engineering of Public Welfare for the construction of the HospitaPdel Niño. ${ }^{2,4}$

By the end of 1934, the work had advanced vertiginously. Although Dr. Gómez said that the construction exhibited a large number of functional errors, caused by ignorance of what a hospital for children should bbe. While these problems were being discussed, structures belonging to the comb-shaped extensions in the eastern and western sectors began to sink, which caused great concern to the builders and the authorities. ${ }^{40}$

Dr. Eugenio Toussaint Aragón, another of the hospital founders, described this experience in the following way: "On the terrains of the General Hospital, in Colonia Doctores [Doctors' neighborhood], a metal structure was slowly raised on a muddy ground, which was, shortly before, empty lots that flooded dựing rainy season forming lagoons, where the so-called water dogs, small ducks, stopped on their flight to the Lake Texcoco. Daily, I moved through the shore of $₫$ his area aboard the electric tram, crossing sowing lands, which would later be Baja California and Calzada de la Piedad avenues (today, Cuauhtémoc Avenue): For that circumstance, I could see how the building's steel skeleton was gaining height, until it reached the fifth level, where it stopped: the structure began to sinkand bend, since the lagoons had been filled with garbage from the Doctors neighborhood, and the ground did not have the solidity to tolerate the weight of a largescale work". 6 
Moreover, in the 1930s, Mexico's experience in soil mechanics was reduced, which seriously affected the hospital's foundation. With great disappointment, the construction had to be suspended for its study, and despite applying foundation laying measures again, they never gave the least benefit despite its high cost. For almost three years, the long-awaited hospital was abandoned to its fate. The disappointment spread in the emerging Mexican pediatrics, where only the sad comments of a situation that was expected to be irremediable were heard. ${ }^{4}$

The political movements in Mexico brought changes in the State secretariats. With each change, a new pilgrimage through vestibules and corridors began, trying to convince the new authorities to assist the hospital's cracked construction and the rusted steel bars that were tearing down. However, it was not possible to arouse interest in the problem in any authority. By then, the Public Charity disappeared, and the Assistance Secretariat was created to replace it. ${ }^{4}$

\section{A new hope}

At the end of 1934, General Lázaro Cárdenas became the President of the Republic and named Mr. Silvestre Guerrero as the attendant of the assistant secretary. At that time, Dr. Federico Gómez was called as a pediatrician to Los Pinos residence, to care for the President's newborn son. Every two weeks, he visited his patient, always waiting for an opportunity to talk about the Hospital del Niño, still under construction. With the advice of the presidential residence secretary (Miss Vázquez Gómez), he developed a project to gather all the dispersed offices, somehow, related to the protection of healthy children and the care of sick children, which could resolve the problem of the Hospital del Niño, whose construction was abandoned. ${ }^{4,6}$

Dr. Gómez's proposal was approved, and General Cárdenas created the Departamento Autónomo de Asistencia Social Infantil [Autonomous Department of Child Social Assistance], appointing his physician, Dr. Salvador Zubirán, as director, and Dr. Federico Gómez as general secretary. The first agreements of this department were to carry out a study that would bring up the Hospital del Niño, whose work was suspended for several years. Studies went back and forth without reaching any viable conclusion until the outstanding architect José Villagrán García was called for the project advice. However, changes came to the cabinet of General Cárdenas, and the brand-new department was incorporated into the Secretaría de Asistencia Social [Secretary of Social Assistance]. ${ }^{4}$
Due to the social and medical pressure to continue the construction, the President called a board of engineers and architects who were authors of several studies. According to Dr. Gómez, the President listeñed to them with the dour patience of his character, and at the end he asked the critical question: "That great riveted steel structure like a large cage could collapse, seriously endangering the personnel and the sick children's life, considering the fact that its structure isfuneven at the endings?". The engineers and architects replied: "The steel frame attached to the structure $\overline{\text { can- }}$ not be divided despite the partial subsidence of its ends. The movements as a whole imply a minimum danger for the staff and the sick children". The President answered, "In this case, I set the work out to be continued, equipped, and put into operation. The Assistance secretariat will provide the budget for that purpose". For this reason, on June 20, in 1938, the conclusion of the hospital was authorized, forming a commission composed of the architect José Villagrán García and the doctors Federico Gómez Santos, Jơrge Muñoz Turnbull, and Roberto Sánchez Messieck.

After a long phase of indecision, the work continued, and the pediatricians once again had the hope of finding a shelter for sick children and an appropriate stimulus for their service and teaching concerns.

\section{The longed-for end}

The activity in the construction of the Hospitabdel Niño, promoted by José Villagrán García, was an effervescence of work, ideas, and projects. At the beginhing of the 1940s, crystallizations were observed. The new President of the Republic, General Manuel Ávila Camacho, entrusted, fortunately for the Mexican pediatrics and in particular, for the hospital under construction, Dr. Gustavo Baz Prada as Secretary of Public Assistance and Dr. Salvador Zubirán as undersecretary ${ }^{4,6}, \bar{\omega}$

At that time, it was necessary to overcome a newoostacle: World War II, since the necessary materials and equipment were acquired abroad and had begun tô be scarce. However, a budget was obtained to send doctors who were going to be heads of service to hospitals in the United States, so that they would learn work programs and technical and administrative organization. According to Viesca and Díaz, by 1942, it could be said that the Secretary of Assistance had already awarded ten doctors abroad. Some of them were already back, and the fields of specialization of their choice were Medicine, Surgery, Anesthesiology, Physiotherapy, Pathological Anatomy, and Hospital Techniques. Unfortunately, existing reports 


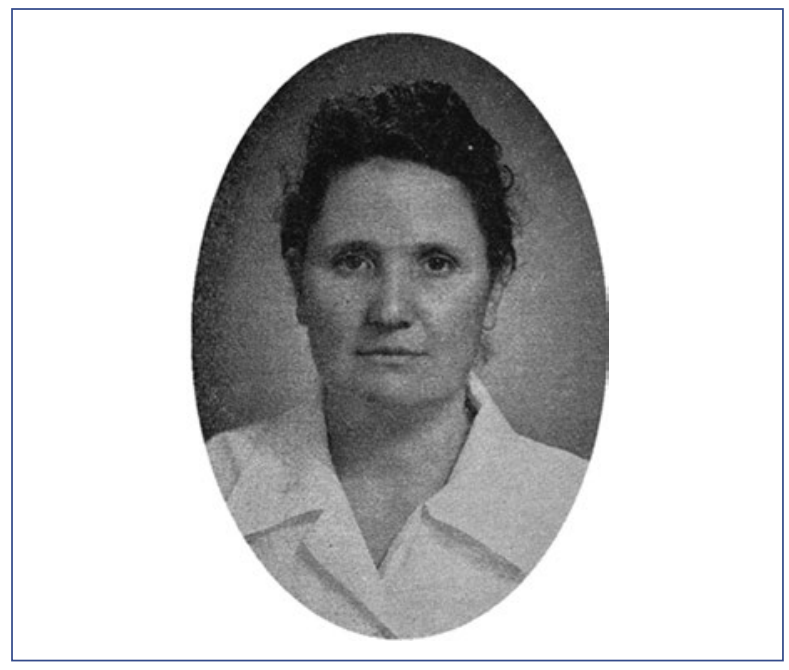

Figure 3. Nurse Carmen Gómez Siegler, first Chief of Nurses of the Hospital Infantil de México, 1943.

do not record the names of the awarded doctors. However, everything seems to indicate that among them were Jesús Lozoya Solís, Alejandro Aguirre, Carlos Herrera, Felipe Cacho, and Guillermo de Ovando. ${ }^{8}$ Another doctor who also received a scholarship was Dr. Rigoberto Aguilar Pico, as Dr. Aguilar himself points out: "We still remember the extensive activity before the inauguration carried out by Dr. Gómez and his collaborators. We also remember the enthusiasm with which all those designated as heads of service went abroad, mainly to the United States, to visit and to study in the most accredited pediatric hospitals". 9 Similarly, a pediatric nursing course for registered nurses was carried out, a small group among those who had passed the course was sent to improve their knowledge at the Children's Hospital and the Nursing School of the North-Western University of Cleveland, Ohio, under the direction of what would be the head nurse of the hospital, Carmen Gómez Siegler (Fig. 3). 4,8

Upon returning from their apprenticeship, nurses and doctors dedicated themselves to teaching what they had learned in their respective fields, developing training courses for all the personnel who wanted to join the hospital, which forced them to put the classrooms into operation, firstly, to offer the courses mentioned. 4,6,10

It should be mentioned that, in his report of September 1942, President Ávila Camacho mentioned for the first time the institution, officially, as Hospital Infantil [Children's Hospital]. ${ }^{11}$

\section{The inauguration}

At the beginning of 1943, it was estimated that the hospital's capacity would be of 600 beds distributed in the body of the building, whose layout was maintained as a central body with six extensions as a "comb teeth." The services were distributed as follows: in the basement, physiotherapy, central pharmacy, section for asylee mothers, admission and storage of clothes for asylum children, central kitchen, staff dining room, general stores, mortuary and corpses amphitheater. On the first floor, the X-ray service, social work, external polyclinic, emergency, blood bank, dental surgery,-government offices and dressing rooms for doctors and visitors, laboratories (including research with its vivarium, pathology and experimental), photography and photomicrograph service, cooking, sterilization, and products delivery. The second floor would house the medical rooms for children from 2 to 14 years old and the teaching section with its classroom, library, "and archives. The third would go to mixed, premature, nursing, medical, and surgical specialties, such as škin diseases and syphilis, ophthalmology and otolaryngology, milk laboratory, and the offices and rooms of male internal doctors. The fourth would be for surgical services; finally, the fifth would be dedicated to tuberculosis and infectious patients, rooms, and classrooms for female internal doctors. ${ }^{8}$

On April 17, 1943, the newspapers announced the inauguration of the hospital on the last day of that month. In one of the notes, in addition to mentioning the role that the almost inaugurated hospital should play in teaching, Dr. Federico Gómez made a transcendental statement confirming that he would leaveshis private practice to devote himself exclusively to the hospital, a situation he had already been doing, abecause he had set up an office which would be the basement of the hospital ${ }^{10}$. At that time, the number and nature of the staff that would work in the Hospital Infantil [Children's Hospital] had already been established, consisting of the staff who would partially participate in hospital work and those who would live in the hospital, among which were Dr. Federico Gómez Santos as a director; four residents (Jesús Lozoya Solís and Felipe Cacho, resident and surgical assistant; Alejandro Aguirre and Carlos Herrera, medical residents, and Fernando Madero and Rodolfo Muñoz Encisö as his assistants); 18 internal doctors; the administrator, and the head nurse, Carmen Gómez Siegler. ${ }^{8}$

The first generation of internal doctors consisted of four women and fourteen men: Raúl Ávila, Lázaro Benavides, Beatriz Bienvenu, Francisco Cisneros, Fernando Espinosa Ogarrio, Marcelino Figueroa, Güittermina García, Alfonso González Ordóñez, Carmen Labra Robredo, Antonia E. Machain, Manuel Méndez 


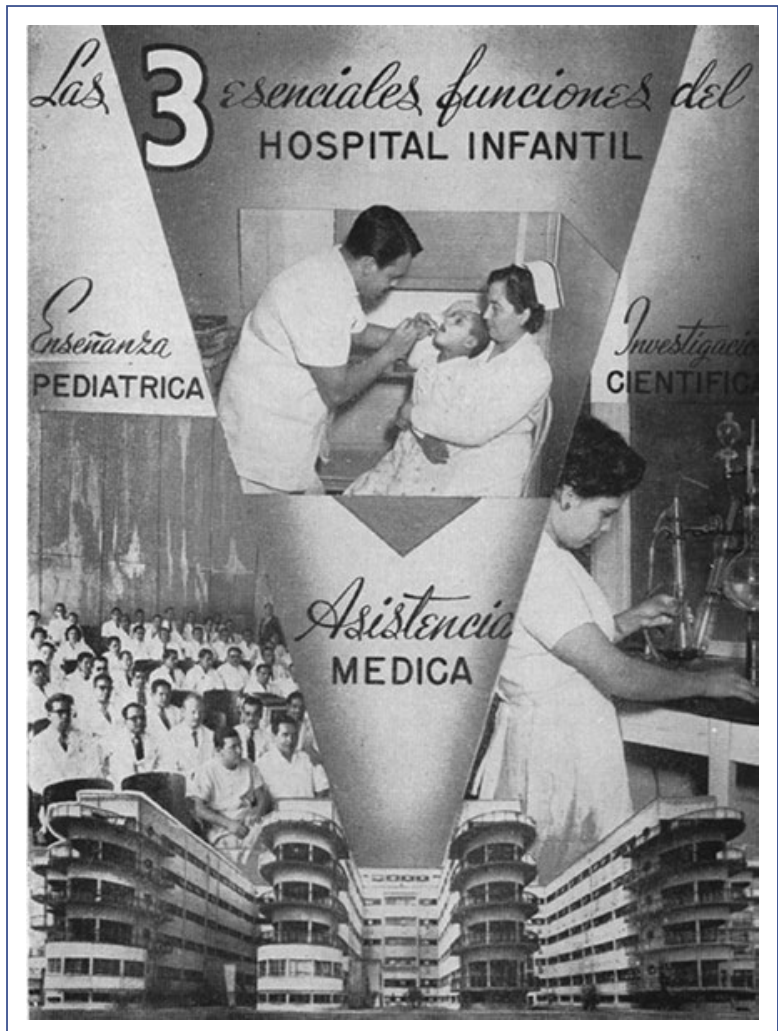

Figure 4. The three essential functions of the Hospital Infantil de México Federico Gómez.

Matías, José Martínez Posada, Heriberto Montemayor, Rodolfo Quintero, Elías Romero Sánchez, Carlos Vidales, Rubén Lavalle and Guillermo Zárate Mijangos. ${ }^{6,8}$ The external doctors were Carlos Abad Martínez, Rigoberto Aguilar Pico, Jesús Álvarez de los Cobos, Luis Berlanga Berumen, Manuel Berumen, Hermilo Castañeda, Gustavo Castillo Díaz, Nicandro Chávez, Guillermo De Ovando A., Juan Farril, Demófilo González, Daniel Gurría Urgell, Luis Gutiérrez Villegas, Fernando López Clares, Artemio Gallegos Landeros, Rafael Moreno Valle, Jorge Muñoz Turnbull, Dionisio Pérez Cosío, Antonio Ramírez Ciará, Fermín Reygadas Macedo, Rafael Ramos Galván, Vicente Roqueñí, Maximiliano Salas Martínez, Roberto Sánchez Messieck, Rafael Soto Allende, Herbert Stacpoole, Antonio Torres de Anda, Eugenio Toussaint Aragón, Luis Vargas y Vargas and Alejandro Velasco Zimbrón. ${ }^{6,8}$

Days before the scheduled date, the Secretary of Public Assistance, Dr. Gustavo Baz, addressed the invitations to the opening ceremony of the Children's Hospital that would take place on April 30, 1943, with the presence of the President of the Republic. In this official invitation, the institution was named "Hospital Infantil" [Children's Hospital], which would replace the

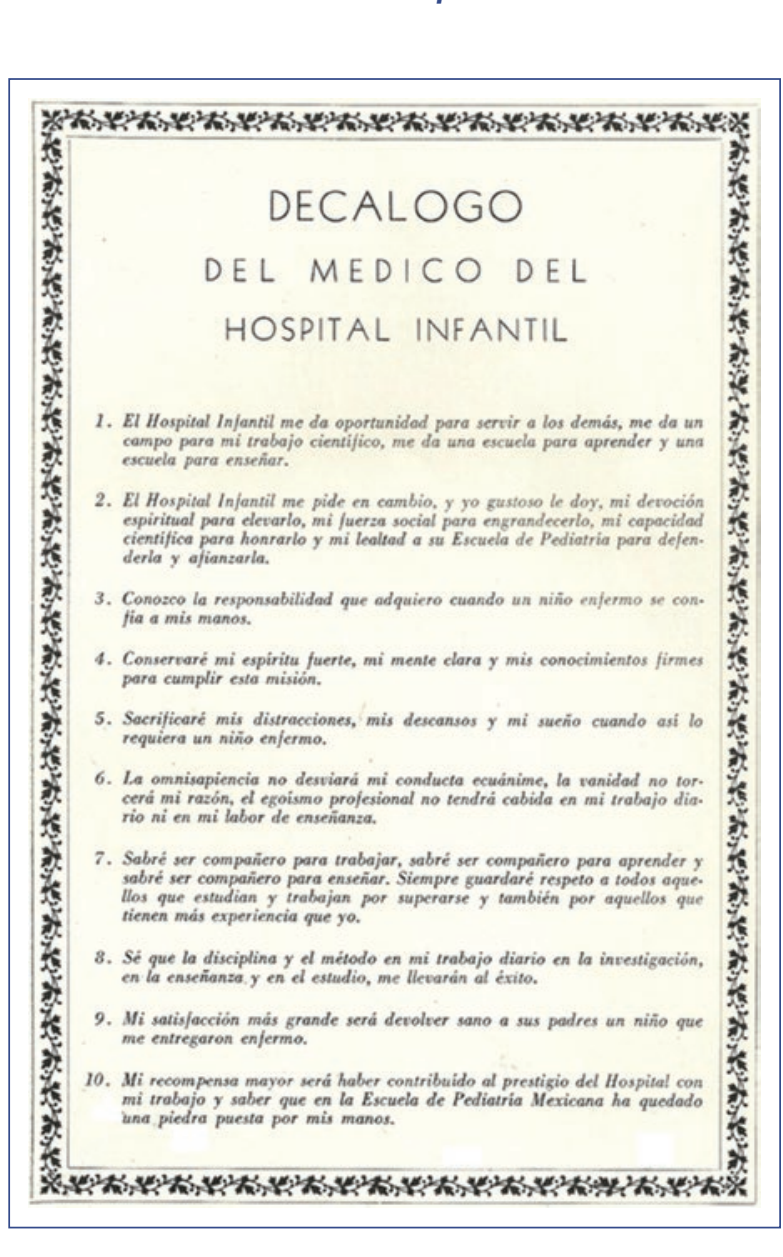

Figure 5. Decalogue from the Hospital Infantil de México.

"Hospital del Niño," as it was known since its inception. Dr. Toussaint points out that the purists of the langưage had criticized the name "Infantil" [Children's] because it alluded to small. However, the public accepted the name without taking into account the Academia de la Lengua [Language Academy] ${ }^{6}$, and its name was ratified with the enactment of the law of its creation published in the Official Gazette on June 23, 1943, which reads as follows:

Article 1. The Hospital Infantil [Children's Hospitall] is created in Mexico City in order to fulfill three essential functions:

a) To provide medical attention, in all its aspects, for sick children, mainly to homeless and low-economic children.

b) To propagate, by all means at its disposal, the teaching of Pediatrics to doctors and medical students and the teaching of Pediatric Nursing to graduate nurses.

c) To promote scientific production and research on the medical-social problems of Mexican children (Fig. 4). 12 Despite the previous announcements, the President of the Republic did not attend the inauguration, apparently due to a respiratory infection, but was represented 
by his brother, General Maximino Ávila Camacho, Secretary of Communication and Public Works, accompanied by Mr. Miguel Alemán Valdés, Secretary of the Governance, Dr. Gustavo Baz, Secretary of Public Assistance, and General Lázaro Cárdenas, Secretary of the National Defense, among others. 6,10

In his inaugural address, Dr. Federico Gómez pointed out the following: "We are celebrating today the long-awaited inauguration of the Hospital, and we already have the idea carried out in front of us. Now, it is up to the doctors and staff that are going to collaborate in the institution to make it work, grow and become prestigious, giving sick children in Mexico the most complete and efficient service that can be given to children in any country on earth. The idea is ambitious, but it is realizable, and we will carry it out. Our goal will be to make this hospital an institution that fulfills three important functions: an excellent service to society, a favorable field for pediatric education, and a fertile environment for the investigation of childhood pathological problems. The social function will give a welcoming refuge to the sick children, ensuring that affection and sympathy make their stay in the hospital less bitter. The teaching function will open its doors to doctors, students, and nurses in the capital and states who wish to specialize and then return to their homeland to spread knowledge that defends the health and life of children. The research function will tend to clarify many deep problems of the diseases of children in Mexico, and its results in the form of scientific production will reach all the corners of the Republic, distributing abundant and optimal harvest between the doctors". ${ }^{\text {? }}$

Ten years later, in his anniversary speech, the founder said: "If the Hospital Infantil [Children's Hospital] resists the test of time along the years without falling into the useless and sleepy routine, encouraged by the permanent spirit of restlessness that now moves it, it will not stagger because its leaders change, nor will it feel threat or anxiety because the authorities are renewed, nor will it tremble in fear of the onslaught of the incomprehensive. It will simply continue on its way, looking calmly at the temporary agitation, staring at its three postulates, full of desires, responsibilities, - and exquisite satisfactions: efficient medical service for sick children, unlimited dissemination of pediatric education and research".13

Today, 75 years after its creation, the founder could say: We have fulfilled!

The Hospital Infantil de México Federico Gomez [Federico Gómez Children's Hospital of Mexico] has withstood the test of time and keeps its principles of assistance, teaching and research intact, fulfilling the commitment established by the founder in the tenth subsection of the Doctor's Decalogue of the Hospital Infantil de México [Children's Hospital of Mexico] $]_{4-4}^{+i} M y$ greatest reward will be to have contributed to the prestige of the Hospital with my work and to know that a stone laid by my hands has remained in the Schoôl of Mexican Pediatrics" (Fig. 5).

\section{Conflicts of interest}

The authors declare no conflicts of interest.

\section{References}

1. Kumate J. Federico Gómez Santos (1897-1980). Bol Med Hosp Infant Mex. 1996;53:300-2

2. Viesca-Treviño C. VI. Los orígenes de la pediatría. Gac Med Mex. 1994;130:510-6.

3. Lozoya-Solís J. Las tres primeras instituciones dedicadas a la asistencia hospitalaria pediátrica en México. Prensa Med Mex. 1966;104-29.

4. Gómez F. La atención al niño enfermo a partir de la Independencia. In: Ávila-Cisneros I, Padrón-Puyou F, Frenk S, Rodríguez-Pinto M, editors. Historia de la pediatría en México. Mexico: Fondo de Cultura Económica; 1997. pp. 311-32.

5. Velasco Ceballos R. El niño mexicano ante la caridad y el estado. Mexico: Editorial Cultura; 1935.

6. Toussaint-Aragón E. Hospital Infantil de México «Dr. Federice-Gómez"1943-1983. Mexico: Imprenta Aldina; 1983

7. Gómez F, Benavides L. Hospital Infantil México, D.F. 1943-1953. Informe de Labores. Mexico: Talleres Gráficos de la Nación; 1953.

8. Viesca-Treviño C, Díaz-De Kuri M. Hospital Infantil de México Federico Gómez, medio siglo de historia. México: Gráfica, Creatividad y Diseño, S.A de C. V; 2001.

9. Aguilar-Pico R. El Hospital Infantil de México. Gac MedवMex. 1963:93:1155-64.

10. Chico-Ponce de León F. Crónica hemerográfica de la fundaciōn del Hospital Infantil de México Federico Gómez. Bol Med Hosp InfantMex. 2010;67:1-49.

11. Cámara de Diputados LX Legislatura. II Informe de Gobierno delPresidente Constitucional de los Estados Unidos Mexicanos ManuebÁvila Camacho. September 1, 1942. Mexico; 2006.

12. Diario Oficial de la Federación de México (1943, June 23). Ley que-crea el Hospital Infantil en esta ciudad.

13. Gómez Santos F. Palabras del director (unpublished). Bol Medॄ̄ Hosp Infant Mex. 1968;25:48-9. 